\title{
Article
}

\section{Development of Biopolymeric Hybrid Scaffold-Based on AAc/GO/nHAp/TiO 2 Nanocomposite for Bone Tissue Engineering: In-Vitro Analysis}

\author{
Muhammad Umar Aslam Khan ${ }^{1,2,3,4, *}$, Wafa Shamsan Al-Arjan ${ }^{5}$, Mona Saad Binkadem ${ }^{6}$, Hassan Mehboob ${ }^{7}$, \\ Adnan Haider ${ }^{8}{ }^{(}$, Mohsin Ali Raza ${ }^{4}$, Saiful Izwan Abd Razak ${ }^{1,9}$, Anwarul Hasan ${ }^{10,11}$ and Rashid Amin ${ }^{12}$
}

check for updates

Citation: Aslam Khan, M.U.; Al-Arjan, W.S.; Binkadem, M.S.; Mehboob, H.; Haider, A.; Raza, M.A.; Abd Razak, S.I.; Hasan, A.; Amin, R. Development of Biopolymeric Hybrid Scaffold-Based on AAc/GO/nHAp/ $\mathrm{TiO}_{2}$ Nanocomposite for Bone Tissue Engineering: In-Vitro Analysis. Nanomaterials 2021, 11, 1319. https:// doi.org/10.3390/nano11051319

Academic Editor: Cristina Martín

Received: 9 April 2021

Accepted: 9 May 2021

Published: 17 May 2021

Publisher's Note: MDPI stays neutral with regard to jurisdictional claims in published maps and institutional affiliations.

Copyright: (c) 2021 by the authors. Licensee MDPI, Basel, Switzerland. This article is an open access article distributed under the terms and conditions of the Creative Commons Attribution (CC BY) license (https:// creativecommons.org/licenses/by/ $4.0 /)$.
1 BioInspired Device and Tissue Engineering Research Group, School of Biomedical Engineering and Health Sciences, Faculty of Engineering, Universiti Teknologi Malaysia, Skudai 81300, Johor, Malaysia; saifulizwan@utm.my

2 Department of Polymer Engineering and Technology, University of the Punjab, Quaid-e-Azam Campus, Lahore 54590, Pakistan

3 Institute for Personalized Medicine, School of Biomedical Engineering, Shanghai Jiao Tong University, Shanghai 200030, China

4 Department of Metallurgy and Materials Engineering, CEET, University of the Punjab, Quaid-e-Azam Campus, Lahore 54590, Pakistan; mohsin.ceet@pu.edu.pk

5 Department of Chemistry, College of Science, King Faisal University, Al-Ahsa 31982, Saudi Arabia; walarjan@kfu.edu.sa

6 Department of Chemistry, Faculty of Science, University of Jeddah, Jeddah 21589, Saudi Arabia; mbinkadem@uj.edu.sa

7 Department of Engineering Management, College of Engineering, Prince Sultan University, Rafha Street, Riyadh 11586, Saudi Arabia; hmehboob@psu.edu.sa

8 Department of Biological Sciences, National University of Medical Sciences, Rawalpindi, Punjab 46000, Pakistan; adnan_phd@outlook.com

9 Center for Advanced Composite Materials, Universiti Teknologi Malaysia, Skudai 81300, Johor, Malaysia

10 Biomedical Research Center, Qatar University, Doha 2713, Qatar; hasan.anwarul.mit@gmail.com

11 Department of Mechanical and Industrial Engineering, Qatar University, Doha 2713, Qatar

12 Department of Biology, College of Sciences, University of Hafr Al Batin, Hafr Al Batin 39524, Saudi Arabia; rashida@uhb.edu.sa

* Correspondence: umar-786@sjtu.edu.cn or umar007khan@gmail.com

Abstract: Bone tissue engineering is an advanced field for treatment of fractured bones to restore/regulate biological functions. Biopolymeric/bioceramic-based hybrid nanocomposite scaffolds are potential biomaterials for bone tissue because of biodegradable and biocompatible characteristics. We report synthesis of nanocomposite based on acrylic acid (AAc)/guar gum (GG), nanohydroxyapatite (HAp NPs), titanium nanoparticles $\left(\mathrm{TiO}_{2} \mathrm{NPs}\right)$, and optimum graphene oxide (GO) amount via free radical polymerization method. Porous scaffolds were fabricated through freezedrying technique and coated with silver sulphadiazine. Different techniques were used to investigate functional group, crystal structural properties, morphology/elemental properties, porosity, and mechanical properties of fabricated scaffolds. Results show that increasing amount of $\mathrm{TiO}_{2}$ in combination with optimized GO has improved physicochemical and microstructural properties, mechanical properties (compressive strength (2.96 to $13.31 \mathrm{MPa}$ ) and Young's modulus (39.56 to $300.81 \mathrm{MPa})$ ), and porous properties (pore size (256.11 to $107.42 \mu \mathrm{m}$ ) and porosity (79.97 to $44.32 \%$ )). After $150 \mathrm{~min}$, silver sulfadiazine release was found to be $\sim 94.1 \%$. In vitro assay of scaffolds also exhibited promising results against mouse pre-osteoblast (MC3T3-E1) cell lines. Hence, these fabricated scaffolds would be potential biomaterials for bone tissue engineering in biomedical engineering.

Keywords: biocompatibility; biodegradation; cytotoxicity; drug delivery; graphene oxide; hybrid scaffolds; nanocomposite; tissue engineering 


\section{Introduction}

Bone is a porous natural composite with a variety of properties that can be used to heal or repair a fractured bone by replacing or reconstructing new tissues [1]. Artificial tissue grafting has become increasingly popular in recent years as a way to overcome the limitations of traditional approaches (i.e., allograft or autografts). Immune rejection, pathogen transfer, pain, infection, and limited availability are all addressed [2,3]. Tissue engineering (TE) is a cutting-edge method of constructing and designing scaffolds that combines materials engineering and life science techniques to aid in the reconstruction and regeneration of new tissues. Bone regeneration, based on scaffolds, is vital for healing bone defects caused by trauma, tumors, resection, and bone deformities. For successful defected bone regeneration, interaction between bone-related cells and scaffolds is critical [4].

The key benefit of TE is the ability to choose a cost-effective and optimized method for scaffold designing that closely resembles the fracture site. The synthesis of scaffolding composite materials for TE is still difficult due to the complex human body and sensitive biological system. Engineering bioresorbable, biodegradable, and biocompatible scaffolds for tissue regeneration is a feasible alternative to meet the standard requirement for host bone [5,6]. With controlled degradations, these fabricated scaffolds should not cause cytotoxic, immunogenic, inflammatory, or any other host reaction, allowing for new tissue regeneration $[7,8]$. The surface properties of the scaffolds (physicochemical and morphological) are essential to establish tissue response and cell growth. For bone tissue engineering, a scaffold with optimized pore size and interconnected porosity is desirable [9]. Scaffolds with the desired physical shape support vascularization of ingrown tissues. It is essential for cell penetration and migration to effectively vascularize the growth of new tissue to have maximum porosity $(90 \%)$ and suitable pore diameter (minimum 100 and maximum $450 \mu \mathrm{m})[10,11]$. For the cost-effective industrial development of bone tissue engineering scaffolds, economic synthesis methods are preferable.

Polymers (e.g., polysaccharides, poly(-hydroxy ester), hydrogels, or thermoplastic elastomers) have been used as biomaterials for TE in the previous era [12,13]. Different essential minerals or bioactive ceramics (such as calcium phosphates and bioactive glasses or glass ceramics) have been investigated to strengthen the microstructure that maintains structural integrity to grow new tissues. Recently, hybrid composites based on polymers and ceramics have received attention to achieve microstructural, physicochemical, and biological activities to enhance their interaction with host tissue [14]. Additionally, efforts were made to develop polymeric composite scaffolds with sustained delivery of bioactive molecules (including growth factors or antibiotics) to heal tissues or treat fractured bones to aid wound healing [11]. For bone regeneration, bioceramics such as hydroxyapatite (HAp), tricalcium phosphate (TCP), and bioactive glass (BGs) have been widely used. Due to their chemical similarity to the mineral phase of natural bone, these bioceramics are extremely biocompatible. The osteogenesis process also involves the interaction of osteoblast and osteoclast cells with bioceramics in order to repair or heal fractured bone [15]. The bioceramics stimulate osteoblast cells to differentiate and proliferate, which has a lot of potential in dental and orthopedic applications. These bioceramics have also been used to coat metallic implants in order to improve their interaction with host bone tissue, but they are brittle, resulting in poor mechanical strength. These bioactive ceramics are complicated to shape into a desired shape, like HAp, which has a long degradation time but low mechanical strength due to its brittle nature. Because of its favorable osteoconductivity, HAp, one of the substantial constituents of native bone, has been frequently used in bone tissue engineering [16,17]. In load-bearing applications, the porous structure of HAp cannot hold up. This critical issue can be carefully addressed by using polymeric composites to improve microstructural features. Bioceramics (i.e., HAp, BGs, and TCP) may have optimized microstructures for defected bone by combining biodegradable polymers (such as poly(glycolic acid), chitosan, arabinoxylan, and guar gum) with biodegradable polymers (including poly(glycolic acid), chitosan, arabinoxylan, and guar gum) [18]. These biodegradable polymers also act as a binder that reduces the brittleness of HAp. To achieve 
porous scaffolds, several methods have been previously reported to fabricate biopolymer composite scaffolds (often including solvent casting and particulate leaching or phase separation, etc.). The freeze-drying method, on the other hand, can produce more porosity with appropriate pore size. As a result, freeze-drying is a common method to fabricate porous scaffolds that can be controlled by ice crystal growth [19].

In this study, we developed polymeric nanocomposites with GG, acrylic acid (AAc), nano-hydroxyapatite (HAp NPs), nano titanium oxide $\left(\mathrm{TiO}_{2} \mathrm{NPs}\right), \mathrm{GO}$, and $\mathrm{N} \mathrm{N}^{\prime}$-methylene bisacrylamide (NN-MBA). The homogenized slurry of these hybrid polymeric nanocomposites was poured into a 24 -well cell culture plate, and the freeze-dry method was used to fabricate porous scaffold. FTIR, SEM/EDS, and UTM were used to characterize the structural, morphological, and mechanical properties of these hybrid nanocomposite scaffolds. Water contact angle, biodegradation (phosphate buffer saline (PBS) solution), and swelling analyses (water and PBS solution) were used to determine wetting, biodegradation, and swelling behavior of these nanocomposite scaffolds. A PBS solution was used to determine the drug release profile of these hybrid nanocomposite scaffolds. Brunauer-Emmett-Teller (BET) was used to determine pore size and porosity. These hybrid nanocomposite scaffolds were tested in vitro against MC3T3-E1 cell lines. These hybrid nanocomposite scaffolds have the potential to be used as biomaterials in bone tissue engineering.

\section{Materials and Methods}

\subsection{Materials}

Guar gum is a natural polymer and is isolated from the seeds of Cyamopsis tetragonoloba. Its $\mathrm{pH}$ is 6.4, and it contains galactomannan polysaccharides. Sigma-Aldrich Malaysia (Selangor, Malaysia) supplied guar gum (CAS\# G4129-500G), acrylic acid (AAc), and N,N'-methylene bisacrylamide (MBAA). Graphene oxide flake (CAS\# 763713-1G) contains carbon $(44.4 \%)$ and water $(15.5 \%)$, and is amphiphilic in nature. It improves the physicochemical, mechanical, and biocompatibility properties of the polymeric nanocomposites materials. Hydroxyapatite nanoparticles ( $<100 \mathrm{~nm}$ particle size, $\geq 95 \%)$, titanium dioxide nanoparticles ( $<100 \mathrm{~nm}$ particle size, $\geq 98.3 \%$ ), phosphate buffer saline (PBS) solution, and ethanol were supplied by Sigma-Aldrich, Selangor, Malaysia. All chemicals and reagents were analytically graded and used without any purification.

The MC3T3-E1 cell lines were supplied by the American Type Culture Collection, Manassas, VA 20110, USA. L-glutamine penicillin/streptomycin, Alpha-MEM ( $\alpha-M E M)$, and fetal bovine serum (FBS) were purchased from ThermoFisher Scientific (Waltham, MA, USA), Hyclone Laboratories Inc. (Logan, UT, USA).

\subsection{Synthesis of Polymeric Nanocomposite}

Guar gum powder $(2 \mathrm{~g})$ was dispersed in deionized water $(30 \mathrm{~mL})$, and the solution was transferred to a two-neck round bottom flask. HAp-NPs (1.4 g) and different quantities of $\mathrm{TiO}_{2} \mathrm{NPs}(0.1,0.2,0.3$, and $0.4 \mathrm{~g})$ were suspended in the deionized water, and the suspension was added to the two-neck round bottom flask. The mixture was stirred for $45 \mathrm{~min}$. After $45 \mathrm{~min}, \mathrm{GO}(0.3 \mathrm{mg})$ was added to the mixture being optimized in our previous work [5]. The mixture was stirred to homogenize for $30 \mathrm{~min}$ at $65^{\circ} \mathrm{C}$ under a nitrogen atmosphere. The homogenization of the mixture was followed by the addition of monomer (AAc $(0.50 \mathrm{~mL})$, crosslinker (MBA) crosslinker $(0.05 \%$ of AAc), and initiator (potassium persulfate $(0.05 \mathrm{~g})$ ). The reaction was carried out for $3 \mathrm{~h}$ at $65{ }^{\circ} \mathrm{C}$ under a nitrogen environment. After completing the reaction, heating was stopped, nitrogen gas was removed, reaction media were allowed to cool, and then the mixture was vacuumfiltered. The unreacted chemicals were removed from the product by washing the reaction media 3 to 4 times with excessive deionized water. The polymeric hybrid nanocomposite materials were oven-dried overnight at $50^{\circ} \mathrm{C}$. The proposed chemical schematic reaction mechanism is presented in the Scheme 1. The dried powder was saved in zip-lock plastic bags for further use and labeled (XPH-1, XPH-2, XPH-3, and XPH-4) corresponding to 
the different amounts of $\mathrm{TiO}_{2} \mathrm{NPs}(0.1,0.2,0.3$, and $0.4 \mathrm{~g})$. The schematic of the proposed chemical is illustrated in Figure 1A.

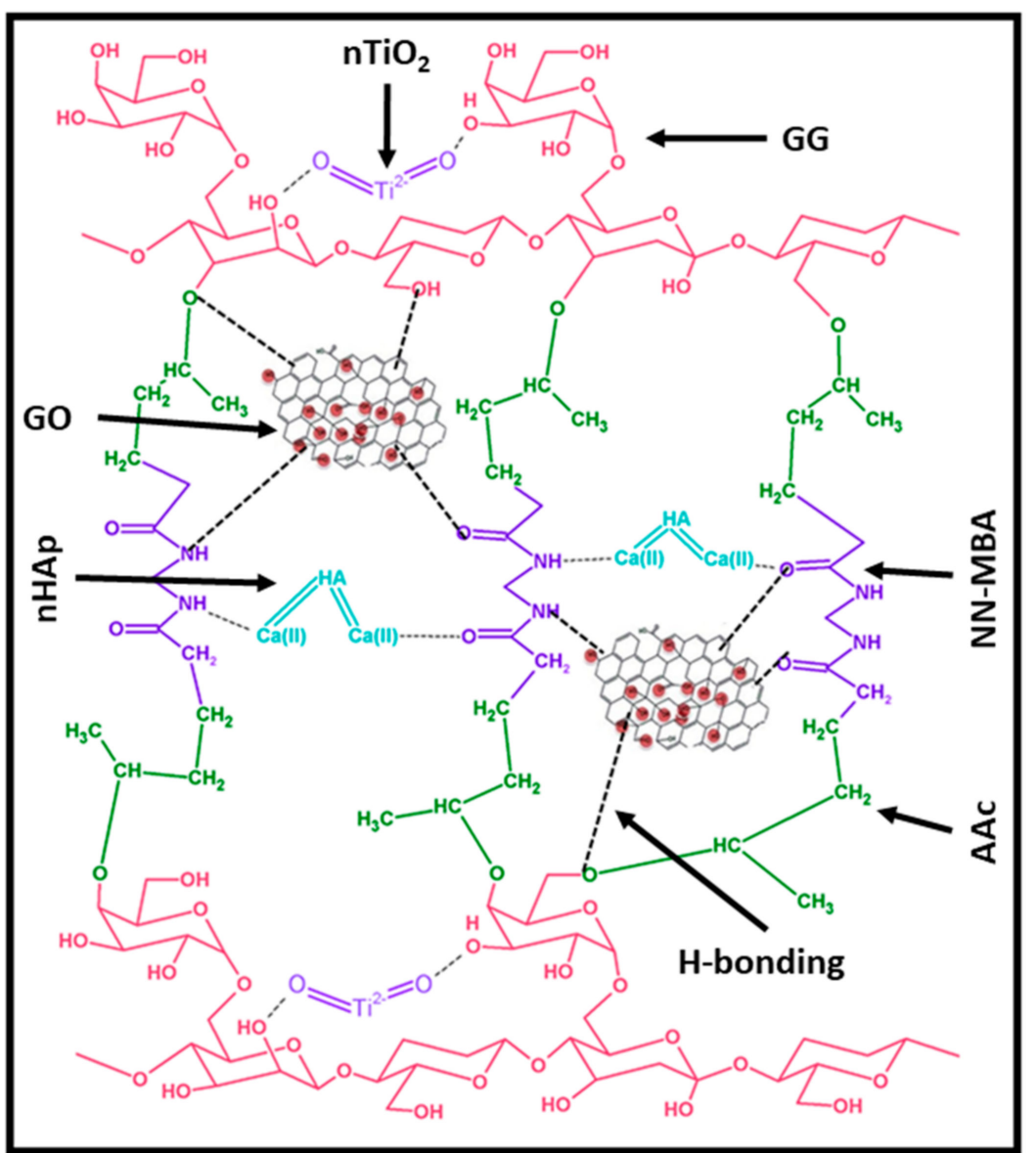

Scheme 1. The proposed chemical schematic reaction mechanism presenting the synthesis of polymeric nanocomposite via free radical polymerization reaction and among the organic (GG, AAc, GO, and NN-MBA) and inorganic materials (nHAp and $\mathrm{nTiO}_{2}$ ).

\subsection{Fabrication of Porous Hybrid Nanocomposite Scaffolds}

The polymeric composite hybrid nanocomposite scaffolds were fabricated through the freeze-drying technique. Briefly, the polymeric hybrid nanocomposites powder ( $5 \mathrm{~g}$ ) of the corresponding formulation was dispersed in deionized water to make the slurry and was poured into a cell culture plate (24-well) to freeze at $-80{ }^{\circ} \mathrm{C}$ for $48 \mathrm{~h}$. The dimension of each well of 24 cell culture plate is as follows: height $=1.74 \mathrm{~cm}$, diameter $=1.56 \mathrm{~cm}$. It was then freeze-dried to achieve porous, cylindrical, and well-dried scaffold without any crack or deformation as presented in Figure 1B. 


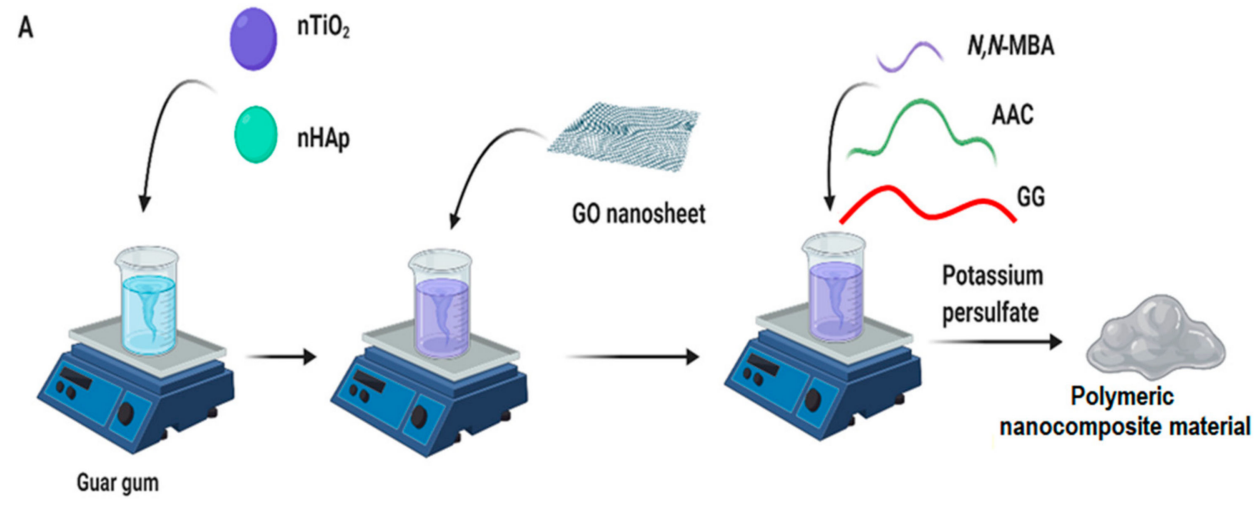

B
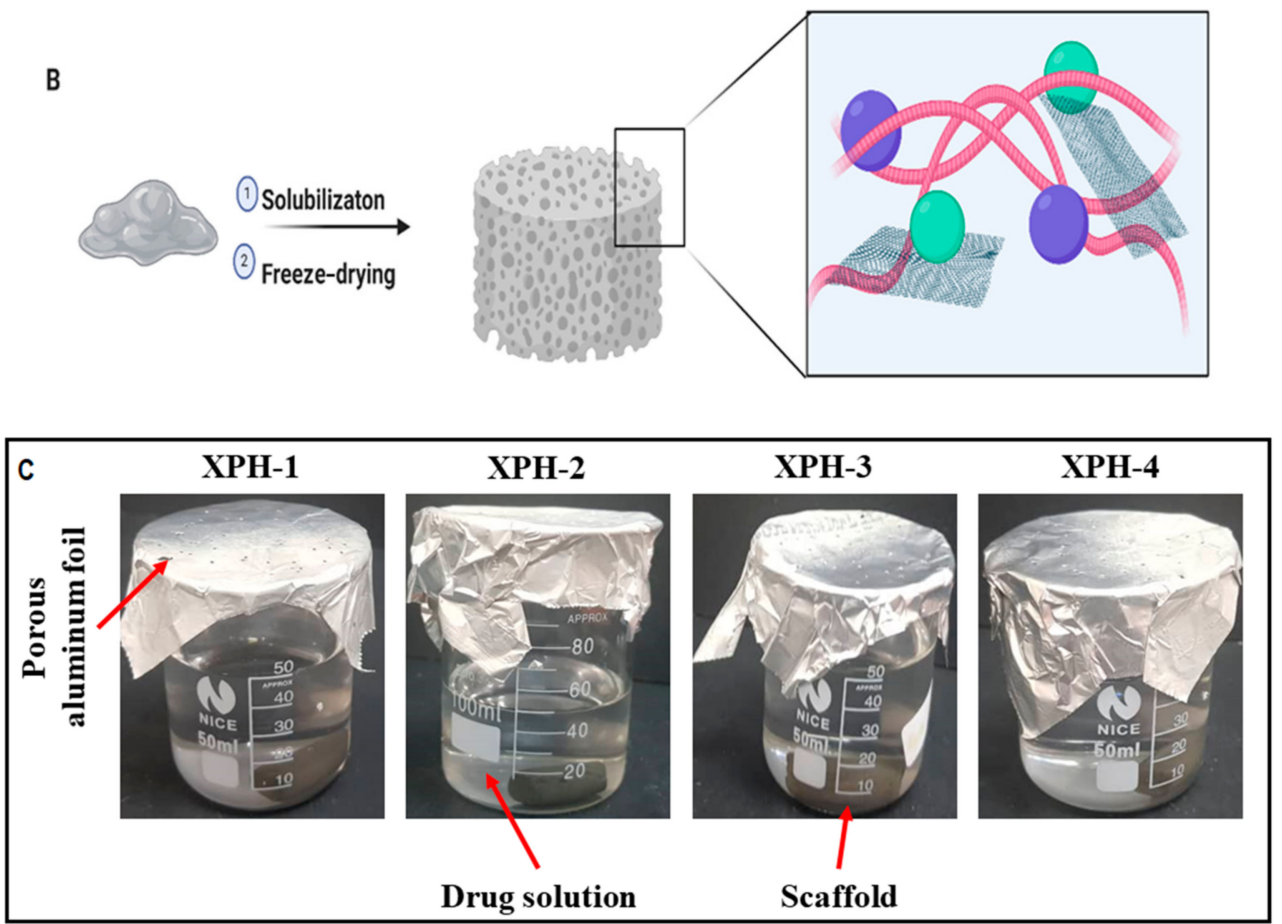

Figure 1. (A) Synthesis of polymeric matrix of nanocomposite through free radical polymerization. (B) Fabrication of porous scaffold via freeze-drying technique. (C) Silver sulfadiazine drug was loaded by a simple dip and dry method.

\subsection{Drug Loading}

Silver sulfadiazine is a famous antibacterial drug, and it is helpful in killing disease or infection-causing pathogens during and after implantation. Silver sulfadiazine $(2.5 \mathrm{mg})$ was weighed carefully and dissolved in ethanol $(5 \mathrm{~mL})$. The dissolved drug was then dropwise added in deionized water ( $45 \mathrm{~mL}$ ) to make a homogeneous solution by continuous stirring. These hybrid nanocomposite scaffolds were dipped into the drug-containing beaker and the beaker was wrapped with aluminum foil. These beakers containing corresponding hybrid nanocomposite scaffolds were kept in the oven $\left(50^{\circ} \mathrm{C}\right.$ until complete evaporation of solvent) by making small holes in the aluminum foil for slow solvent evaporation to deposit silver sulfadiazine as illustrated in Figure 1C. The silver sulfadiazine release was observed in PBS buffer media under in vitro conditions ( $\mathrm{pH} 7.4$ at $37^{\circ} \mathrm{C}$ ). The specific amount of PBS media $(5 \mathrm{~mL})$ was taken from the beaker, and the spectrum was run in a double beam UV-Vis spectrophotometer to record drug release. The PBS buffer solution was taken as a standard reference, and the graphical cumulative release of the drug. 


\section{Characterizations}

\subsection{FTIR Analysis}

The FTIR spectrum was recorded to determine the functional group analysis of hybrid nanocomposite scaffolds using Fourier transformation infrared (Shimadzu FTIR-8100A, Tokyo, Japan). The scanning range was $4000-400 \mathrm{~cm}^{-1}$ with average scans (150) and resolution $4.0 \mathrm{~cm}^{-1}$.

\subsection{XRD Analysis}

The crystalline and amorphous behavior of the hybrid nanocomposite scaffolds was determined using X-ray diffraction (XRD). Bruker AXS D8 (Kontich, Belgium) Advance $X R D$ was used at $40 \mathrm{kV}$ voltage and $30 \mathrm{~mA}$ current with $\mathrm{Cu} \mathrm{K} \alpha$ radiation $(1.540 \AA)$. The XRD analysis was conducted under a fixed angle ranging from $10^{\circ}$ to $70^{\circ}$.

\subsection{SEM-EDS Analysis}

The structural morphology of hybrid nanocomposite scaffolds was analyzed using scanning electron microscopy (SEM) (JEOL-JSM 6480, Peabody, MA, USA) coupled with energy dispersive spectroscopy (EDS). These hybrid nanocomposite scaffolds were welldried and were gold-sputtered before analysis.

\subsection{Brunauer-Emmett-Teller (BET) Analysis}

The Brunauer-Emmett-Teller (Micromeritics Gemini II 2370, Norcross, GA, USA) was used to determine the porosity and pore sizes of hybrid nanocomposite scaffolds. The analysis was performed in triplicate.

\subsection{Mechanical Testing}

The strain-stress analysis of the hybrid nanocomposite scaffolds was measured through a universal testing machine (UTM, Testometrics, Rochdale, UK). The compression strength of the cylindrical hybrid nanocomposite scaffolds (with dimensions $1.5 \mathrm{~cm}$ (width) and $1.7 \mathrm{~cm}$ (height)) was determined at a speed of $0.5 \mathrm{~mm} / \mathrm{min}$. The stress-strain curve was recorded for each sample. The mechanical tests were conducted in triplicate.

\subsection{Wetting Analysis}

The hydrophilic/hydrophobic characteristics of hybrid nanocomposite scaffolds were observed via contact angle meter (XCA-50) (VCA-Optima, AST Inc., Tacoma, WA, USA). The slurry of different formulations was poured into Petri dishes and oven-dried $\left(45^{\circ} \mathrm{C}\right)$ to observe the contact angle. The water drop was placed over dried films after various time intervals ( 1 and $5 \mathrm{~min}$ ), and the test was carried out in triplicate.

\subsection{Swelling Analysis and Biodegradation}

The swelling of biomaterials is an important characteristic that facilitates interaction between the biological system and biomaterials. Swelling also regulates the controlled release of therapeutic agents. The well-dried hybrid nanocomposite scaffolds were weighted $(50 \mathrm{mg})$ carefully before analysis. The swelling analysis of hybrid nanocomposite scaffolds was conducted in PBS and deionized water media with a $\mathrm{pH}$ of 7.4 at $37^{\circ} \mathrm{C}$. At a specific time, the swollen hybrid nanocomposite scaffolds were taken out by removing excess solvent softly using filter paper to record the actual weight of swelled hybrid nanocomposite scaffolds. These hybrid nanocomposite scaffolds were again put into media to accomplish swelling equilibrium. Equation (1) was used to determine the percentage of swelling.

$$
\text { Swelling }(\%)=\frac{W_{\mathrm{s}}-W_{\mathrm{d}}}{W_{\mathrm{d}}} \times 100
$$

where: " $W_{\mathrm{s}}$ " weight of swollen scaffolds, " $W_{\mathrm{d}}$ " weight of dry scaffold.

Biodegradation is an essential biomaterial phenomenon that helps quick healing of fractured bone. Each hybrid scaffold was weighed accurately $(50 \mathrm{mg})$ and incubated in 
the PBS solution with $\mathrm{pH} 7.4$ at $37^{\circ} \mathrm{C}$ for 30 days. The scaffold was taken out of excess of PBS solution and rinsed with deionized water. Then it was oven-dried $\left(55^{\circ} \mathrm{C}\right)$ for $1 \mathrm{~h}$. Equation (2) was used to determine the percentage of degradation.

$$
\text { Degradation }(\%)=\frac{W_{i}-W_{t}}{W_{i}} \times 100
$$

where: " $W t$ " weight of scaffold at time " $t$ ", " $W_{i}$ " initial weight of the scaffold.

\subsection{Drug Release}

The drug-loaded hybrid nanocomposite scaffolds were placed into PBS solution with $\mathrm{pH} 7.4$ at $37^{\circ} \mathrm{C}$. The PBS solution $(5 \mathrm{~mL})$ was then taken out after every specific time. The drug release was observed using a double beam UV-Vis spectrophotometer at $297 \mathrm{~nm}$ using standard curves. The PBS solution was taken as a reference standard. The cumulative drug release of silver sulfadiazine has been presented via a calibration curve.

\subsection{In Vitro Biological Activities}

\subsubsection{Cell Morphology}

A cellular morphology study was performed on the hybrid nanocomposite scaffolds (XPH-1, XPH-2, XPH-3, and XPH-4). A fine coating of the scaffold was applied on the bottom of 24-well plates in triplicate. The coated plates were sterilized under UV light for $1 \mathrm{~h}$. MC3T3-E1 cell line (mouse pre-osteoblast cell line) purchased from ATCC was maintained in $\alpha-M E M, 10 \%$ FBS, $1 \%$ (2 mM) L-glutamine, 1\% penicillin/streptomycin media and was seeded (5000 cells per $\mathrm{cm}^{2}$ ) in each well of 24 -well plates in triplicate using the same culture media and incubated for 24,48 , and $72 \mathrm{~h}$ under standard in vitro conditions (at $37{ }^{\circ} \mathrm{C}$ with $5 \% \mathrm{CO}_{2}$ and $90 \%$ humidity). The media were removed manually through a micropipette. Then, absolute ethanol was used to fix the cultured cells (5 min at room temperature). Cell morphologies were investigated under the Nikon ECLIPS TS100 (Melville, NY, USA) fluorescence microscope using a $488 \mathrm{~nm}$ excitation filter. Vital dye such as fluorescein diacetate (FDA) was used to avoid the background interference in microscopy created by scaffold coating.

\subsubsection{Cell Viability and Optical Density}

The cell viability and optical density of these hybrid nanocomposite scaffolds (with concentrations $0.50-2.00 \mathrm{mg} / \mathrm{mL}$ ) were determined against MC3T3-E1 cell lines and $0.1 \%$ gelatin (+ive control). The cell culture plates were incubated for 24,48 , and $72 \mathrm{~h}$ under standard in vitro conditions $\left(37^{\circ} \mathrm{C}\right.$ in $5 \% \mathrm{CO}_{2}$ and $90 \%$ humidity). These cells were again incubated into neutral red(NR) media ( $40 \mu \mathrm{g} / \mathrm{mL})$ for $2 \mathrm{~h}$ using a well-reported method, Repetto et al. [20]. These cells were then washed for $20 \mathrm{~min}$ with PBS solution to remove the excess NR stain. Then, dye-staining solution (1\% glacial acetic acid, 49\% absolute ethanol, and $50 \%$ deionized water) was used to destain cells for $10 \mathrm{~min}$. The optical density was observed at $570 \mathrm{~nm}$ using an absorbance microplate reader (ELx-800) (BioTek, Winooski, VT, USA). The percentage of the cell viability was calculated with Equation (3).

$$
\text { Cell viability }(\%)=\frac{O D_{\mathrm{S}}}{O D_{\mathrm{C}}} \times 100 \text {, }
$$

where: “OD ${ }_{\mathrm{S}}$ " sample concentration, "OD ${ }_{\mathrm{C}}$ " positive control.

\subsection{Statistical Analysis}

The quantitative data were analyzed through statistical analysis system software (IBM SPSS Statistics 21). The data were then presented as mean \pm standard error (S.E.) and presented as Y-error bars in figures. The data were performed in triplicate $(\mathrm{n}=3)$, and $p<0.05$ was considered statistically significant. 


\section{Results and Discussion \\ 4.1. FTIR Analysis}

Figure 2A presents the FTIR spectra of the fabricated hybrid nanocomposite scaffolds. The spectral profile shows all the characteristic bands of the functional groups of GG-coAAc, HAp NPs, $\mathrm{TiO}_{2}$ NPs, and GO. The broadband at $3200-3600 \mathrm{~cm}^{-1}$ is attributed to hydrogen bonding $\left(\mathrm{H}\right.$-bonding). The absorption band at $2927 \mathrm{~cm}^{-1}$ is a typical stretching vibration peak of $\mathrm{C}-\mathrm{H}$ [10]. The absorption bands in the range of $1750-1628 \mathrm{~cm}^{-1}$ are attributed to the $\mathrm{C}-\mathrm{O}$ stretching of $\mathrm{GO}$ and $\mathrm{N}, \mathrm{N}^{\prime}$-methylene-bisacrylamide. Since in these hybrid nanocomposite scaffolds, $\mathrm{HAp} \mathrm{NPs} \mathrm{TiO}_{2} \mathrm{NPs}$, and GO are linked through $\mathrm{H}$-bonding with GG-co-AAc polymeric matrix, hence the vibration bands at $\sim 1058 \mathrm{~cm}^{-1}$ and $\sim 1300 \mathrm{~cm}^{-1}$ are attributed to $\mathrm{C}-\mathrm{O}-\mathrm{H} / \mathrm{C}$ deformation modes of polysaccharides, and $\mathrm{C}-\mathrm{O}-\mathrm{H}$ stretching in pyranose of carbohydrates [9]. The absorption peaks at 997, 633, and $543 \mathrm{~cm}^{-1}$ represent $\mathrm{P}-\mathrm{O}$ stretching, $\mathrm{O}-\mathrm{P}-\mathrm{O}$ bending, and HAp NPs, respectively. The characteristic absorption bands at $560-600 \mathrm{~cm}^{-1}$ and $845-1000 \mathrm{~cm}^{-1}$ are attributed to the calcium and phosphate moiety of HAp NPs. Moreover, the absorption peak at $624 \mathrm{~cm}^{-1}$ appears due to $-\mathrm{OH}$, a characteristic peak of HAp NPs [21]. The stretching band from $600-800 \mathrm{~cm}^{-1}$ is attributed to $\mathrm{TiO}_{2}$ NPs, and it is observed that increasing the amount of $\mathrm{TiO}_{2} \mathrm{NPs}$ increases the peak intensities [22]. Hence, it is confirmed from FTIR spectral analysis that the hybrid polymeric nanocomposite materials have been successfully fabricated.
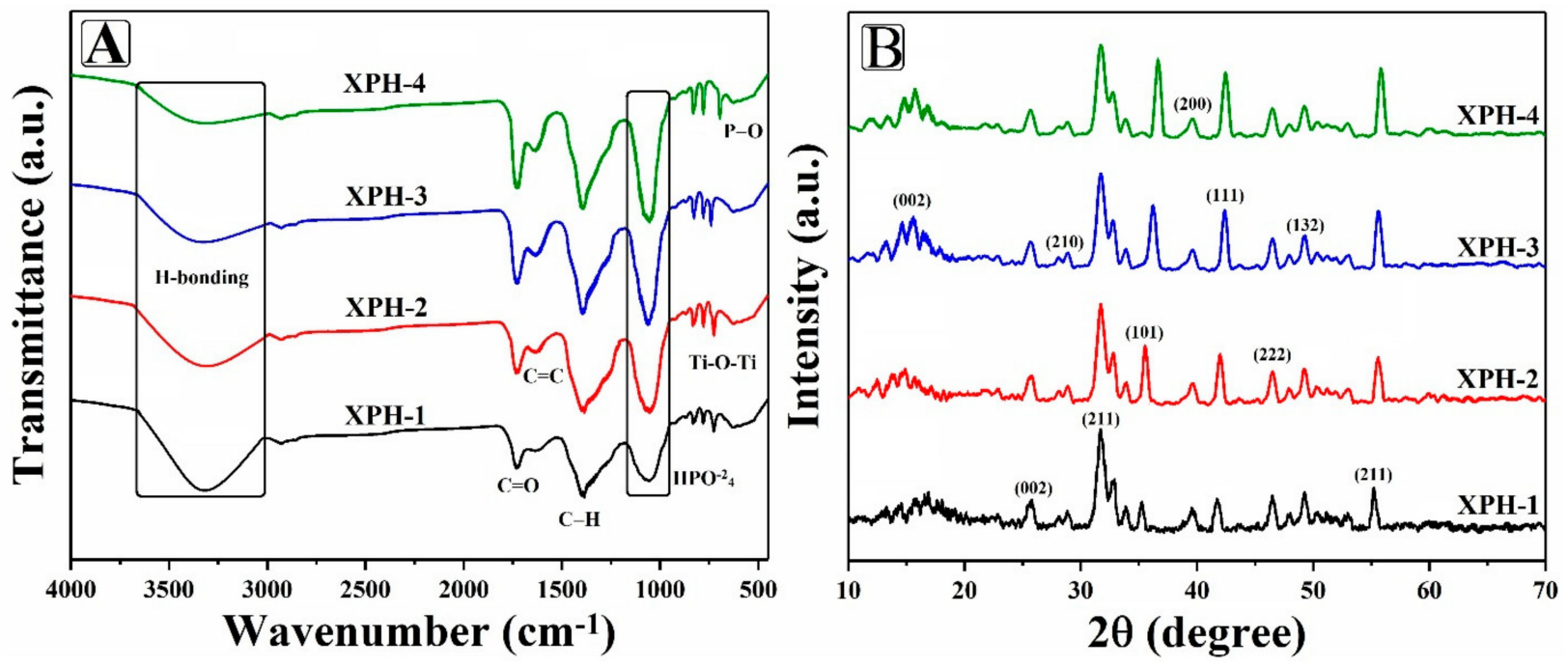

Figure 2. The spectroscopic analysis to determine structural properties of hybrid nanocomposite scaffolds. (A) FTIR spectral profiles to analyze the functional groups. (B) Diffraction spectra to investigate crystalline and amorphous behavior of the hybrid nanocomposite scaffolds.

\subsection{XRD Analysis}

Figure $2 \mathrm{~B}$ presents XRD spectral analysis of the $\mathrm{TiO}_{2} / \mathrm{HAp} / \mathrm{BG}-\mathrm{PVA}$ hybrid nanocomposite scaffolds. The sharp diffraction peaks of HAp NPs were observed at $2 \theta$ of $25.15^{\circ}$, $28.80^{\circ}, 32.10^{\circ}, 39.80^{\circ}, 46.50^{\circ}$, and $48.60^{\circ}$ with corresponding planes (211), (210), (002), (222), and (132) [10]. The cell parameters for HAp NPs, $a=b=9.4000$ and $c=6.9300$, were calculated with the standard hexagonal closest packed (HCP) unit cell plane spacing relationship [23]. These corresponded perfectly to the standard data of hydroxyapatite (JCPDS file number 9-0432) [24]. The crystalline size, $23.29 \mathrm{~nm}$, of the HAp NPs was calculated with the Debye-Scherrer equation [25]. The diffraction peaks at $35.10^{\circ}, 38.21^{\circ}$, $42.21^{\circ}$, and $55.11^{\circ}$ corresponding to (101), (200), (111), and (211) were observed for $\mathrm{TiO}_{2}$ NPs [26]. The crystal planes parameters were calculated with lattice constants $a=b=3.755$ $\AA$ and $c=9.5114 \AA$. These plans may be diffused in hybrid nanocomposite scaffolds and the peak observed at $35.10^{\circ}$ (101) confirms $\mathrm{TiO}_{2}$ NPs anatase phase in hybrid nanocomposite 
scaffolds. The diffraction peak of GO has been located at crystalline plane (002) [27]. There was no diffraction peak observed for BG-co-AAc due to AX and AA's amorphous nature that reduces overall crystalline behavior. The reducing crystalline behavior increased the hydrogen bond formation that imprinted $\mathrm{HAp} \mathrm{NPs} / \mathrm{TiO}_{2} \mathrm{NPs}$ into the polymeric network.

\subsection{Morphological and Elemental Analysis}

Figure 3 SEM shows the micrographs of the hybrid nanocomposite scaffolds at microand nano-scale. All scaffold samples showed evenly distributed connected porosity. The optimum pore size, determined for the scaffold via BET, was $256 \mu \mathrm{m}$ [28]. This pore size is in the range of the standard pore size required for bone cell growth. The standard pore size for better bone cell infiltration and cell adhesion is approximately 100-350 $\mu \mathrm{m}$ [29]. $\mathrm{TiO}_{2}$ NPs played a significant role in controlling pore size and porosity. The increasing amount of $\mathrm{TiO}_{2} \mathrm{NPs}$ decreased the porosity of these hybrid nanocomposite scaffolds from $79.97 \pm 1.32$ to $44.32 \pm 2.14 \%$ and pore size from $256.11 \pm 1.28$ to $107.42 \pm 1.78$. This control over the size and porosity of the pores by $\mathrm{TiO}_{2} \mathrm{NPs}$ is attributed to its ability to crosslink the polymer chains [3,10] physically. The energy dispersive X-ray (EDX) analysis of hybrid nanocomposite scaffolds was performed to determine the chemical composition of hybrid nanocomposite scaffolds. The result shows the existence of carbon (C), calcium $(\mathrm{Ca})$, oxygen $(\mathrm{O})$, phosphorus $(\mathrm{P})$, and titanium $(\mathrm{Ti})$ in the scaffold (Figure 3$)$. The presence of all these elements confirms the existence of $\mathrm{TiO}_{2} / \mathrm{HAp}$ in the polymeric matrix of BG-g-AAc [30].
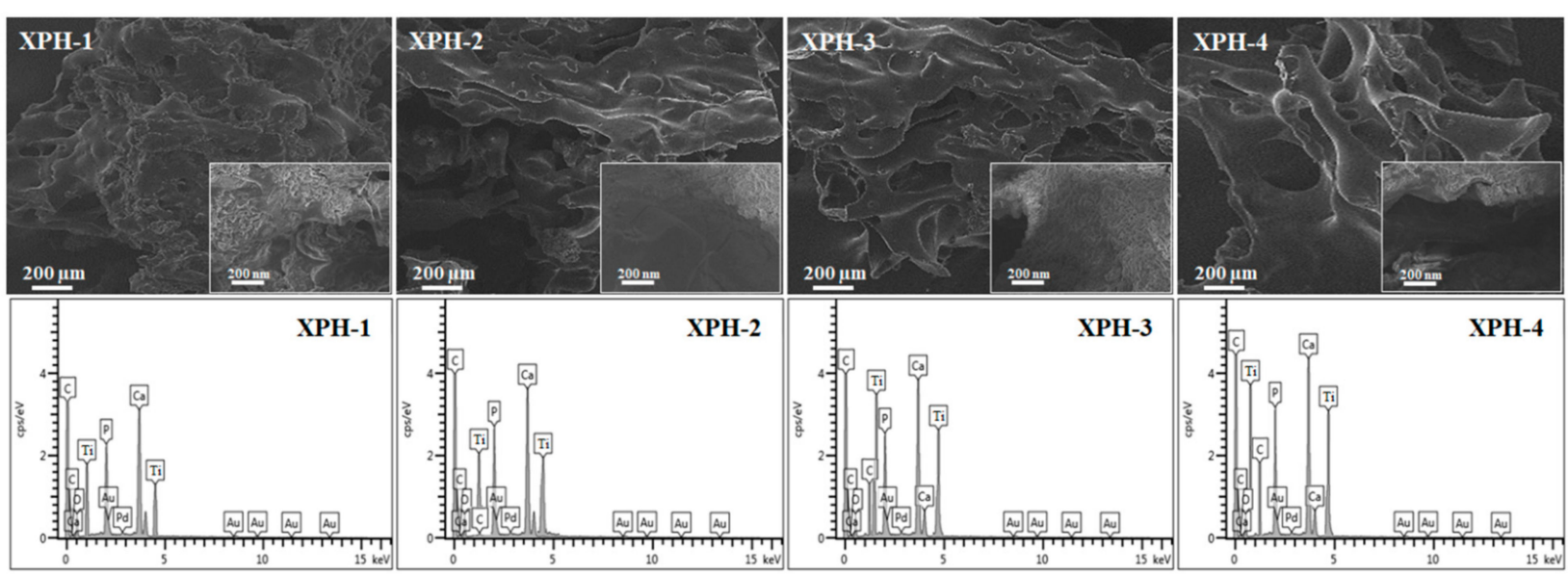

Figure 3. SEM micrographs of the surface of the samples. The inset micrographs show the zoom-in surface of the scaffold samples. The graphs show the EDX spectra of the hybrid nanocomposite scaffolds.

\subsection{Mechanical Testing and BET Analysis}

The mechanical behavior of hybrid nanocomposite scaffolds is presented through the stress-strain curves, as illustrated in Figure 4A. Since GO, HAp NPs, and $\mathrm{TiO}_{2} \mathrm{NPs}$ are well-known potential materials for structural and enhanced mechanical properties [31,32]. Hence, the optimum amount of GO, HAp NPs, and the increasing amount of $\mathrm{TiO}_{2}$ increases the compression strength from $2.96 \pm 1.34$ to $13.31 \pm 2.45 \mathrm{MPa}$ and $19.77 \pm 1.50$ to $34.89 \pm 1.56 \%$ with a maximum Young's modulus $300.81 \pm 1.90 \mathrm{MPa}$ as details have been mentioned in Table 1. It is also observed that the increasing amount of $\mathrm{TiO}_{2}$ decreases the porosity $(79.97 \pm 1.32$ to $44.32 \pm 2.14 \%)$ and pore size $(256.11 \pm 1.28$ to $107.42 \pm 1.78 \mu \mathrm{m})$. The mechanical and porosity data of hybrid nanocomposite scaffolds are presented in Table 1 . The increasing amount of $\mathrm{TiO}_{2}$ NPs provides the additional active sites, which act as crosslinking that increases the mechanical properties of the hybrid nanocomposite scaffolds by reducing porosity and pore size [33]. The relationship between mechanical behavior and porous properties is presented in Figure 4B. The different amount of $\mathrm{TiO}_{2}$ NPs alters the chemical structures that affect interface and matrix grains. HAp NPs play 
a vital role in mechanical and structural mechanical strength by improving mechanical strength because of grain size and grain boundary. The nanosize material provides a higher surface area that interacts with other materials to enhance mechanical strength by regulating porosity and pore size [34].
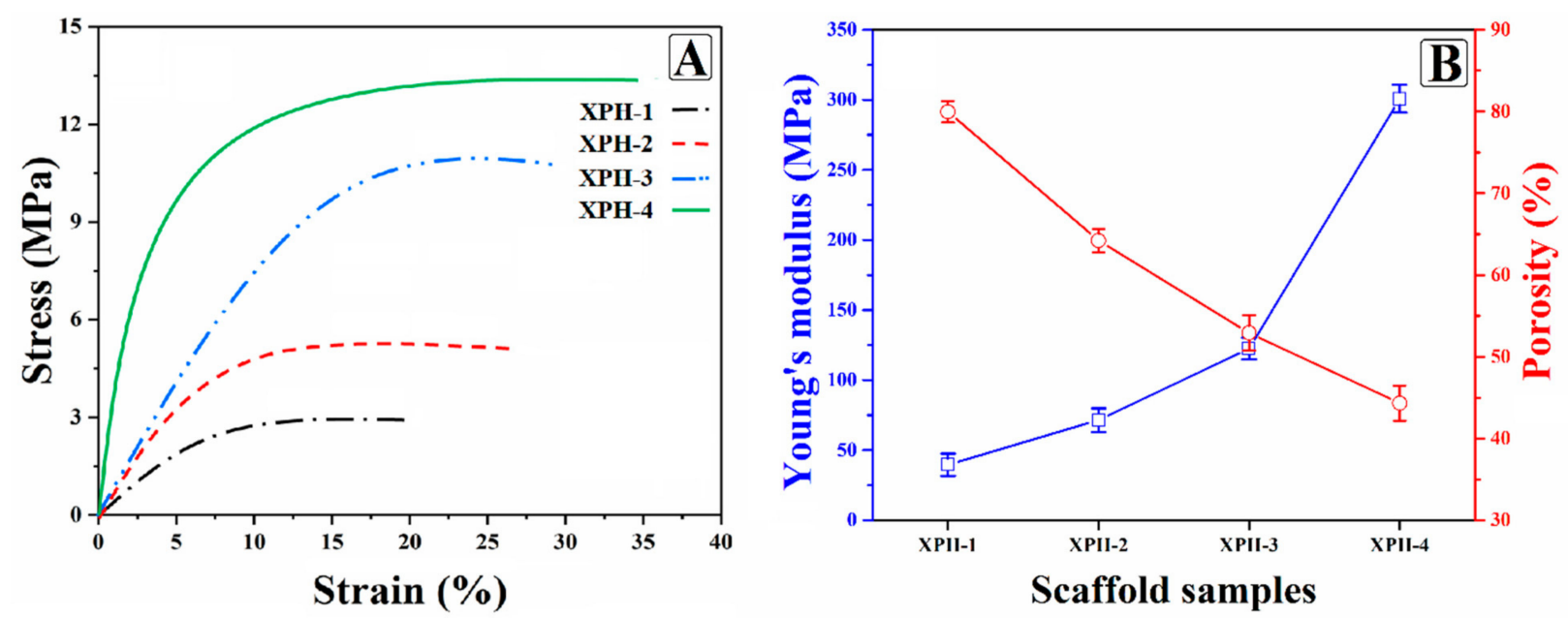

Figure 4. The mechanical behavior of hybrid nanocomposite scaffolds has been investigated through (A) stress-strain curve and (B) relation of Young's modulus and porosity.

Table 1. The mechanical properties, molar crosslink density, pore size, and porosity of polymeric hybrid nanocomposite scaffolds.

\begin{tabular}{ccccccc}
\hline Sample & Strain (\%) & $\begin{array}{c}\text { Strength } \\
\mathbf{( M P a )}\end{array}$ & Young's Modulus (MPa) & $\begin{array}{c}\text { Molar Crosslink } \\
\text { Density }\left(\mathbf{m o l} / \mathbf{m}^{3}\right)\end{array}$ & Pore Size ( $\boldsymbol{\mu m})$ & Porosity (\%) \\
\hline XPH-1 & $19.77 \pm 1.50$ & $2.96 \pm 1.34$ & $39.56 \pm 2.14$ & 0.0053 & $256.11 \pm 1.28$ & $79.97 \pm 1.32$ \\
\hline XPH-2 & $26.64 \pm 2.36$ & $5.18 \pm 2.60$ & $71.43 \pm 1.36$ & 0.0095 & $195.64 \pm 1.64$ & $64.23 \pm 1.43$ \\
\hline XPH-3 & $29.53 \pm 1.90$ & $10.68 \pm 1.12$ & $122.45 \pm 2.24$ & 0.0164 & $142.17 \pm 2.47$ & $52.91 \pm 2.17$ \\
\hline XPH-4 & $34.89 \pm 1.56$ & $13.31 \pm 2.45$ & $300.85 \pm 1.90$ & 0.0402 & $107.42 \pm 1.78$ & $44.32 \pm 2.14$ \\
\hline
\end{tabular}

\subsection{Swelling, Biodegradation, and Wetting Analysis}

When the biomaterial is in contact with the body, it exhibits different behavior and properties during that interaction. It starts absorbing fluids and starts swelling, and after a particular period, it starts degrading to reproduce or regenerate new tissues. Hence, the importance of wet polymeric matrix of hybrid nanocomposite scaffolds cannot be denied for cell adherence, proliferation, and migration in tissue engineering to repair defected organs [35]. These fabricated hybrid nanocomposite scaffolds have different swelling behavior due to the different amount of $\mathrm{TiO}_{2} \mathrm{NPs}$. Figure $5 \mathrm{~A}$ shows the swelling kinetics of the hybrid nanocomposite scaffolds in deionized water and reduced swelling in PBS solution. It is evident from the data that increasing the amount of $\mathrm{TiO}_{2} \mathrm{NP}$ decreased the swelling of the hybrid nanocomposite scaffolds both in deionized water and PBS media at $37^{\circ} \mathrm{C}$. XPH-1 exhibited maximum swelling (deionized water $=91.20 \%$, PBS media $=76.90 \%$ ) due to least amount of $\mathrm{TiO}_{2} \mathrm{NP}$. On the other hand, $\mathrm{XPH}-4$ had minimum swelling (deionized water $=63.30 \%$, PBS media $=54.87 \%$ ) since this sample had the maximum amount of $\mathrm{TiO}_{2}$ $\mathrm{NP}$ content. The varying swelling characteristics of these hybrid nanocomposite scaffolds can be attributed to the very interesting phenomenon where $\mathrm{TiO}_{2} \mathrm{NP}$ acts as a physical crosslinker [36]. The increasing amount of $\mathrm{TiO}_{2} \mathrm{NPs}$ may generate additional crosslinking within polymeric material that decreases material elastic behavior [37]. 

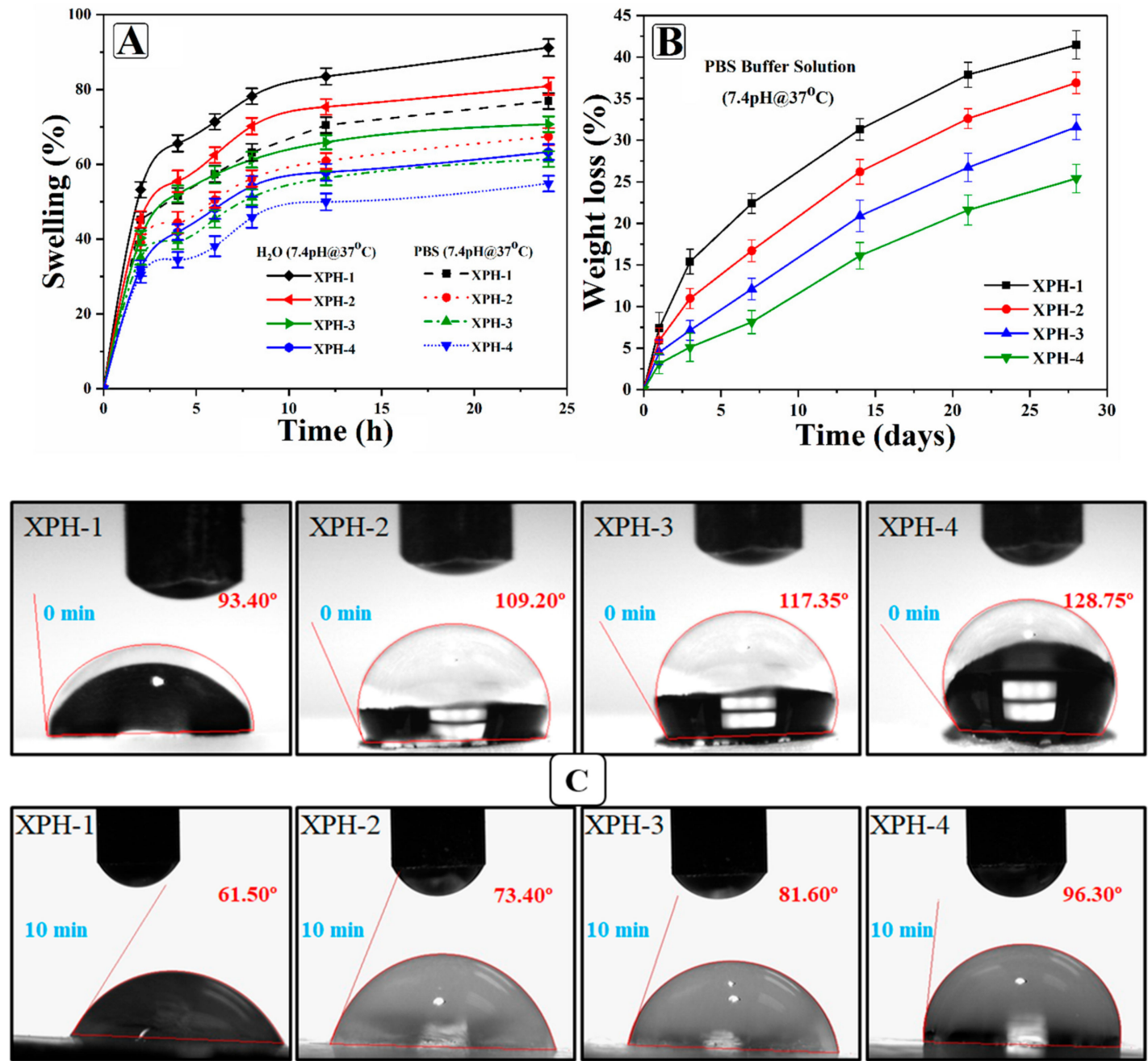

Figure 5. (A) Swelling analysis of the hybrid nanocomposite scaffolds in different media ( $\mathrm{pH} 7.4)$ at $37^{\circ} \mathrm{C}$, (B) degradation of hybrid nanocomposite scaffolds samples in PBS solution (pH 7.4) at $37^{\circ} \mathrm{C}$, and (C) wetting analysis of scaffold samples to determine hydrophilicity and hydrophobicity at room temperature.

The degradation of hybrid nanocomposite scaffolds was investigated in PBS solution at $37^{\circ} \mathrm{C}$, and the percentage of degradation was determined by weight loss as presented in Figure 5B. The increased weight loss was observed as the immersion time in the PBS solution increased. The increasing amount of $\mathrm{TiO}_{2} \mathrm{NPs}$ has an inverse effect on degradation since these are physical crosslinkers. The scaffold sample XPH-1 exhibited maximum degradation and XPH-4 minimum degradation. The different degradation properties of hybrid nanocomposite scaffolds are attributed to the crosslinking ability of the $\mathrm{TiO}_{2} \mathrm{NPs}$. It would be convenient to conclude that increasing the amount of $\mathrm{TiO}_{2} \mathrm{NPs}$ results in increased crosslinking of the hybrid nanocomposite scaffolds, which leads to a more compact structure that is not easily eroded. The increased crosslinking also shifts the already hydrophobic nature of the scaffold to a relatively more hydrophobic nature (Figure 5C) [38].

The wetting analysis of hybrid nanocomposite scaffolds has been analyzed via water contact angle (WCA) measurement to analyze the hydrophilic and hydrophobic behavior of the scaffold. The hydrophilic and hydrophobicity boundary of WCA is $90^{\circ}[39,40]$. Figure 5C shows the WCA for all the fabricated hybrid nanocomposite scaffolds. The WCA of the scaffold increases from $93^{\circ}$ (XPH-1) to $120^{\circ}$ (XPH-4) with the increase in the amount of $\mathrm{TiO}_{2}$ NPs. It shows that the hydrophobic character of the scaffold increases with an increase in the $\mathrm{TiO}_{2} \mathrm{NPs}$. This is well attributed to the $\mathrm{TiO}_{2} \mathrm{NPs}$ ability to crosslink the scaffold physically. 


\subsection{Release of Silver Sulfadiazine}

The PBS solution was used to determine silver sulfadiazine release at $37^{\circ} \mathrm{C}$ to deal with pathogenic activities at the fracture site during implantation. The sustained release of silver sulfadiazine is shown in Figure 6. The sustained, gradual, and prolonged antibacterial drug is an essential phenomenon for antibacterial activities [41]. It was seen from the drug release profile that initially all samples showed quick release but sustained drug release became continuous after $3 \mathrm{~h}$. Sample XPH- 4 has shown maximum drug release as $\sim 14.5 \%$ after $10 \mathrm{~min}$ and $\sim 94.1 \%$ after $150 \mathrm{~min}$.

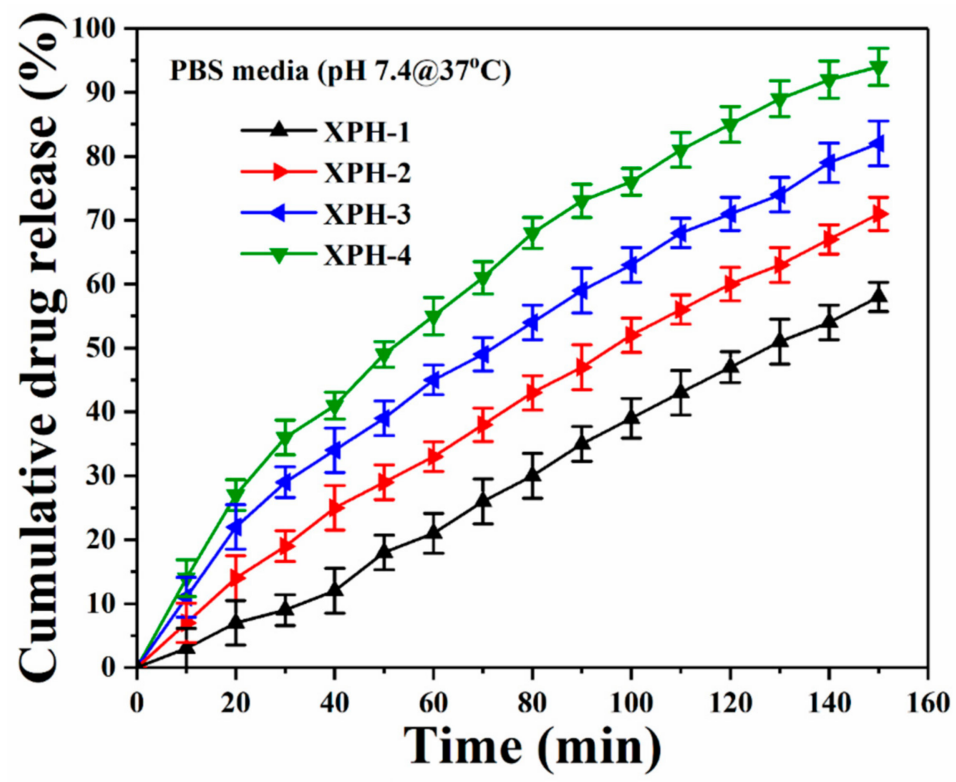

Figure 6. The drug release profile of all polymeric hybrid nanocomposite scaffolds in PBS solution at $37^{\circ} \mathrm{C}$.

In contrast, the least drug release was observed for Sample XPH-1, i.e., $~ 3.7 \%$ after $10 \mathrm{~min}$ and $\sim 58.2 \%$ after $60 \mathrm{~min}$. After $6 \mathrm{~h}$, continuous but sustained release of drug was observed. However, controlled drug release was observed from XPH-4 to XPH-1 due to the different structural properties of the polymeric hybrid nanocomposite scaffolds. Since $\mathrm{XPH}-4$ had the maximum amount of $\mathrm{TiO}_{2} \mathrm{NPs}$ and possessed maximum active site but less $\mathrm{H}$-bonding, the quick release of the drug was observed. On the other hand, XPH-1 had the least amount of GO and had less charge density. It had less capability to attach drugs through H-bonding [42]. The drug may interact more with the polymeric matrix via van der Waal or other attraction forces. That is why sustained drug release was found for sample $\mathrm{XPH}-1$; maximum drug was to show drug release. Hence, sustained and controlled release of the drug is vital to kill disease-causing bacteria during and after bone implantation.

\subsection{In Vitro Activities}

\subsubsection{Cell Viability and Optical Density}

In vitro study of all scaffold specimens against MC3T3-E1 cell lines was performed to determine the bioactivities (i.e., cell viability assay and optical density). The cell viability (Figure 7A) and optical density (Figure 7B) were performed against different concentrations $(0.500,1.000,1.500$, and $2.000 \mathrm{mg} / \mathrm{mL})$ to investigate the effect of concentration. Scaffold samples were incubated under necessary in vitro conditions with MC3T3-E1 cell lines. The cell viability and optical density were recorded after a different time interval $(24,48$, and $72 \mathrm{~h}$ ) [43]. It was observed that increasing concentration and time caused increasing cell viability and cell proliferation. Hence, maximum cell viability and cell proliferation values were observed at maximum concentration and after $72 \mathrm{~h}$ for XPH-4. The scaffold sample XPH-1 contained the maximum amount of $\mathrm{TiO}_{2} \mathrm{NPs}$, which offer an extra active site that helps cell adherence, which leads to cell proliferation with cell cytotoxicity [44]. Meanwhile, 
GO has several oxygen-based functional groups, and it not only enhances microstructural properties, but also facilitates cell adherence and cell proliferation. Whereas hydroxyapatite is famous for enhancing the osteogenesis process. The combined effect of $\mathrm{TiO}_{2}, \mathrm{HAp}$ NPs, and GO alters the physicochemical characteristics that support cellular compatibility. Hence, these scaffold samples have presented cytocompatibility with enhanced cell viability and proliferation, which confirms the biocompatible nature of fabricated hybrid nanocomposite scaffolds.
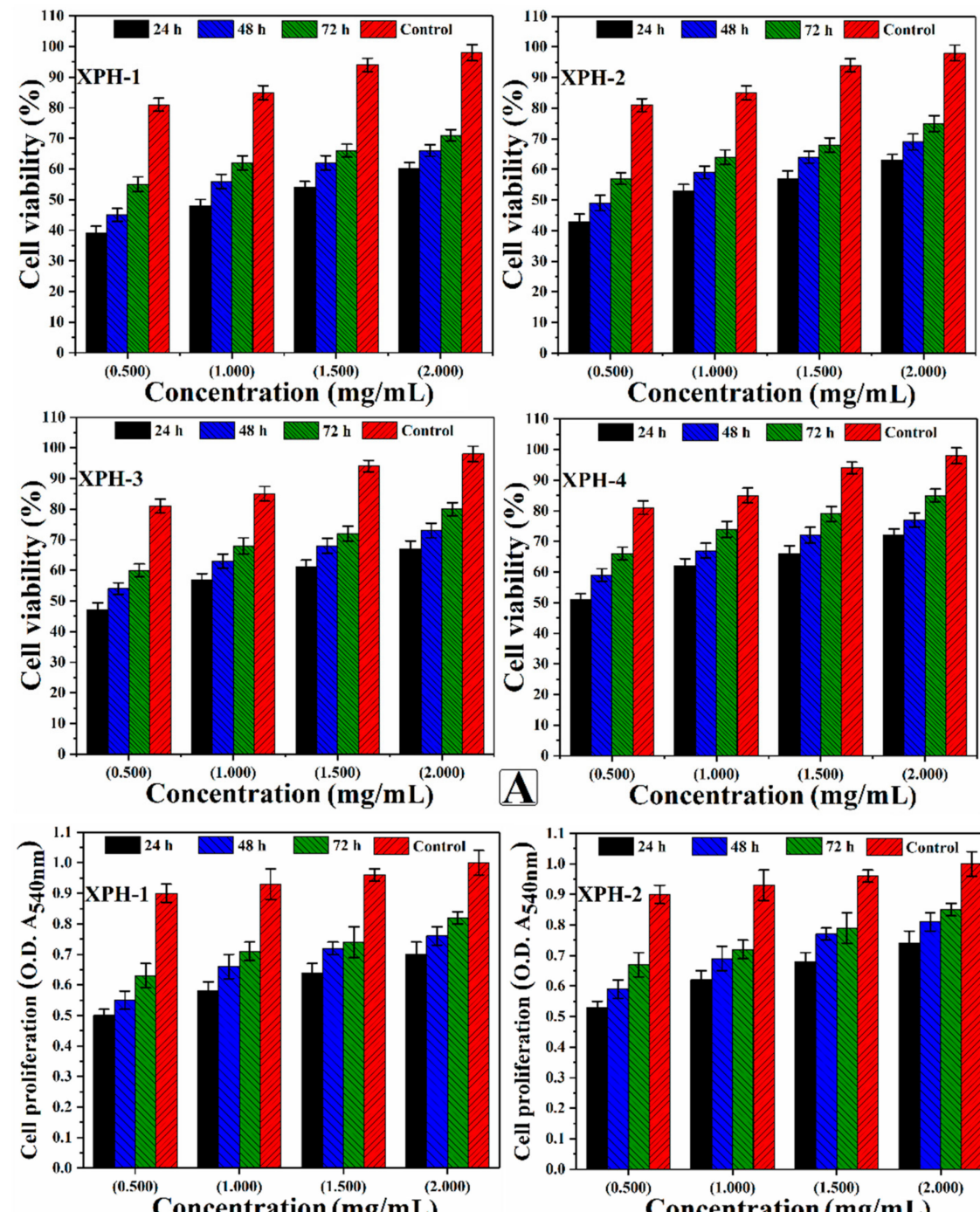

A

Concentration $(\mathrm{mg} / \mathrm{mL})$
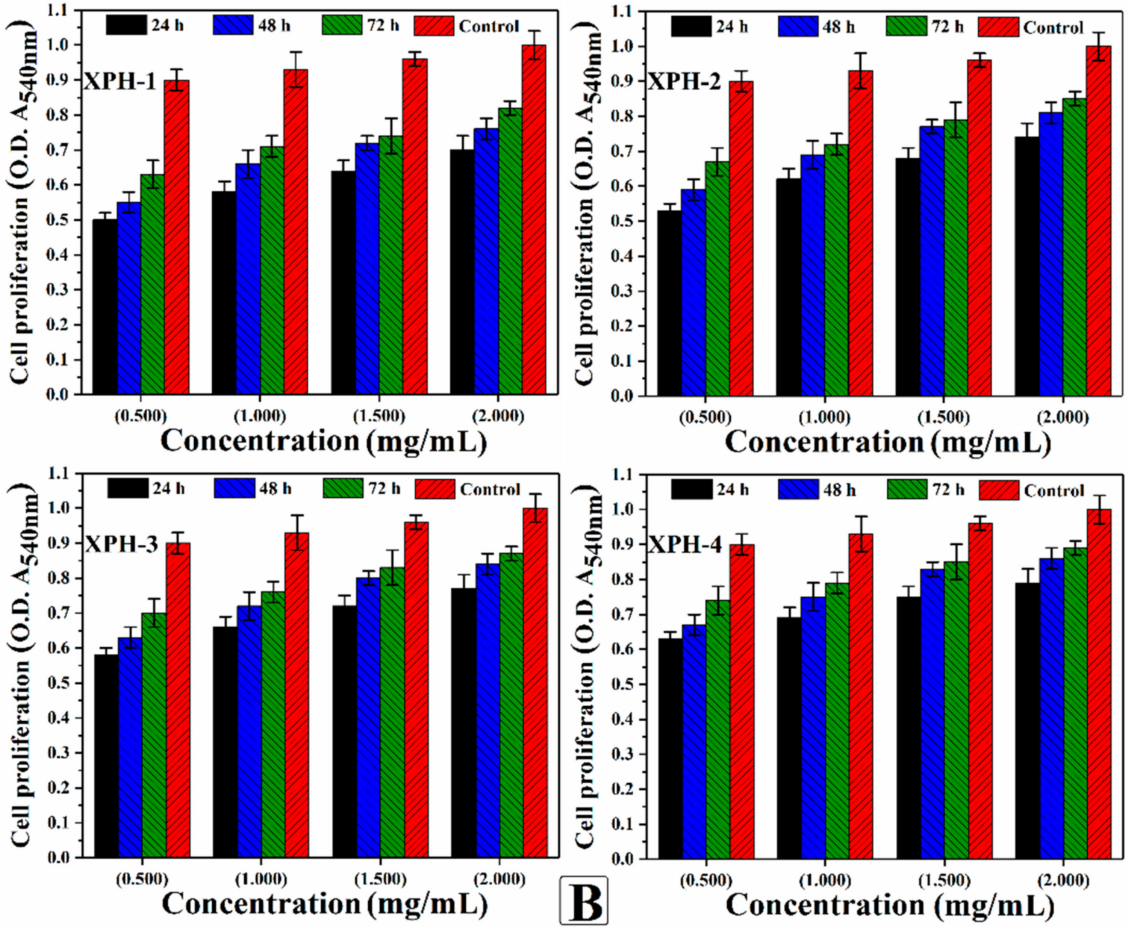

Figure 7. Presents the cellular behavior of MC3T3-E1 against different concentrations $(0.500,1.000$, 1.500 , and $2.000 \mathrm{mg} / \mathrm{mL}$ ) of polymeric hybrid nanocomposite scaffolds at different time intervals (24, 48 , and 72 h) to (A) determine cell viability and (B) optical density under standard in vitro conditions. 


\subsubsection{Cell Morphology}

The scaffold samples were treated with MC3T3-E1 to determine cell adherence and cell morphology, as presented in Figure 8. These scaffold samples are multifunctional $(-\mathrm{COOH}$, $-\mathrm{OPO}_{3},-\mathrm{H}$, and $-\mathrm{OH}$, etc.) due to GO, $\mathrm{HAp} \mathrm{NPs}, \mathrm{TiO}_{2} \mathrm{NPs}$, and polymeric matrix and these factors all together facilitate cell adherence and proliferation with a proper cylindrical shape. These functionalities establish hydrogen bonding with the cell membrane [45]. The increasing amount of $\mathrm{TiO}_{2} \mathrm{NPs}$ increases the active site, which encourages cell adherence, differentiation, and growth due to integrin bonding with the material surface. Initially, the shape of the cell was like a thread (red arrows), and after $24 \mathrm{~h}$, more cell adherence was observed (blue arrow). The scaffold samples (XPH-3 and XPH-4) have a microstructural surface with rough morphology, and after increasing time, clearer cell spreading was observed. Hence, a considerable change in absorbance was presented at different time intervals. The wetting behavior also facilitated communication of material with DNA of host bone that encouraged fracture cell adherence and cell growth to form new bone to regenerate bone [46].

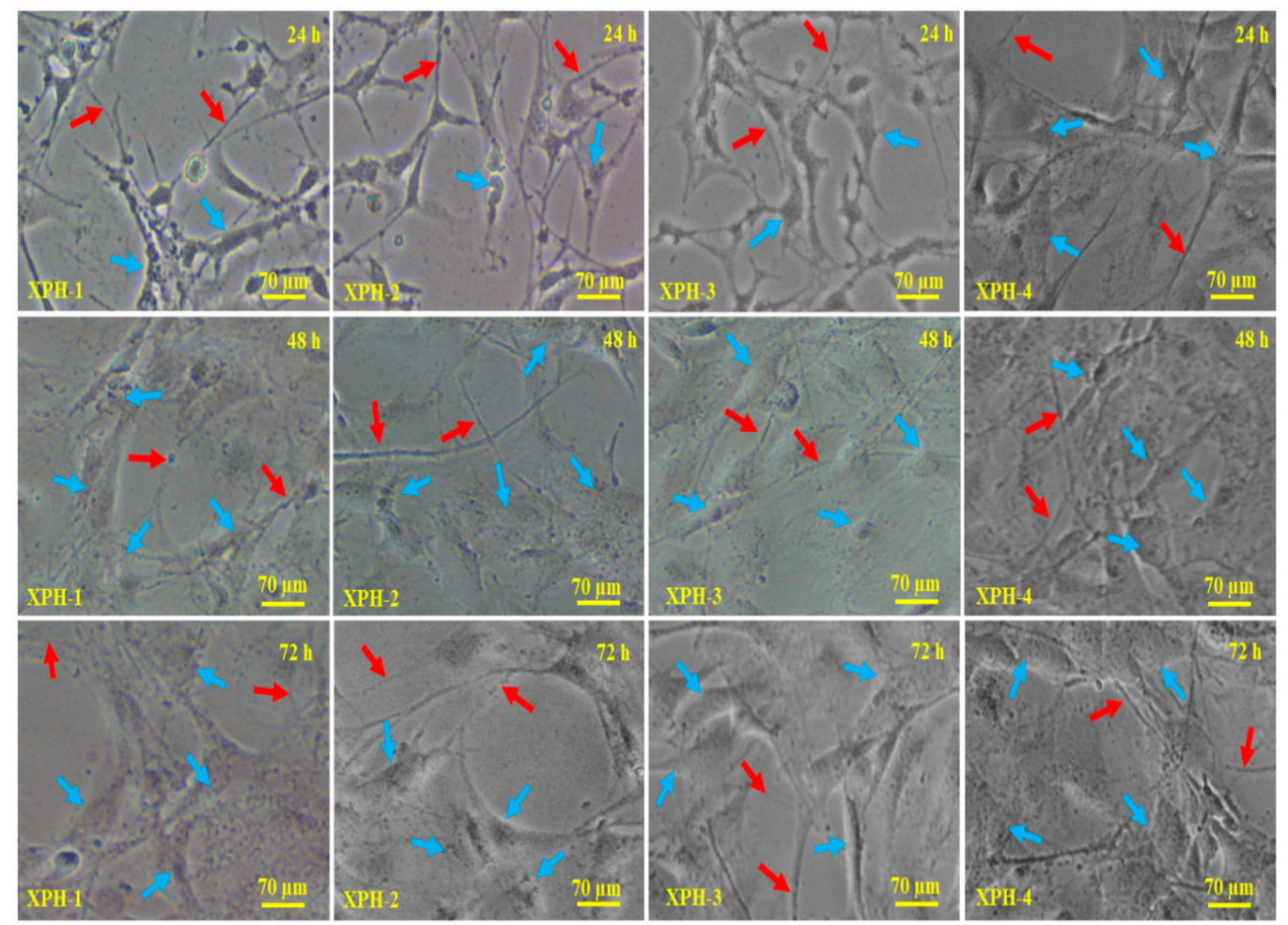

Figure 8. In vitro cell morphology of MC3T3-E1 cells onto the hybrid nanocomposite scaffolds (XPH-1, XPH-2, XPH-3, and XPH-4) at different times (24, 48, and $72 \mathrm{~h}$ ). The red arrows present the thread-like morphologies of the cells whereas the blue arrows show the mature cylinder-like morphologies of the cell.

Furthermore, after $48 \mathrm{~h}$, more cell adherence was observed after quick cylindrical morphology and cell proliferation for all samples. Still, a substantial difference was observed, especially for XPH-3 and XPH-4, as shown in Figure 8. Due to the increased amount of $\mathrm{TiO}_{2}$ NPs with optimized GO, it induced their functionalities throughout the scaffold materials by enhancing physicochemical and biomechanical characteristics. It can also be explained that increasing the incubation time makes the surface more hydrophilic, thus encouraging more cell adherence through hydrogen bonding. Hence, the multifunctional biomaterial is necessary for cell growth to heal fracture bone [47]. 


\subsubsection{SEM Analysis of Cell Culture and Attachment}

The cell adherence and morphology of MC3T3-E1 over the surface of the scaffold have been observed through SEM after $72 \mathrm{~h}$ of cell culture (Figure 9). Cell adherence increased as the amount of $\mathrm{TiO}_{2} \mathrm{NPs}$, increased from XPH-1 to XPH-4. The synergic effect of the $\mathrm{TiO}_{2}$ NPs and GO led to the creation of additional active sites. Cell adherence over the scaffold is visible with different shapes. Most of the cells exhibit well-spreading cylindrical shapes (as evident in the cell morphological section) on hybrid nanocomposite scaffolds by covering the surface [48]. The cell penetration into pore and growth over the surface increased as time increased, and cell culturing is presented with red arrows after 24, 48, and $72 \mathrm{~h}$, as shown in Figure 9. These increasing multifunctional properties and active sites facilitate cell adherence. It also may be explained based on wetting phenomena that hydrogen bonding encourages cell adherence. Hence, rough surface morphologies with enhanced multifunctional properties and wetting together encourage cell adherence due to increasing oxygen-based functional groups that offer H-bonding [49]. The increasing time also improves cell adherence and proliferation by gene expression that facilitates new bone growth to heal fractured bone.
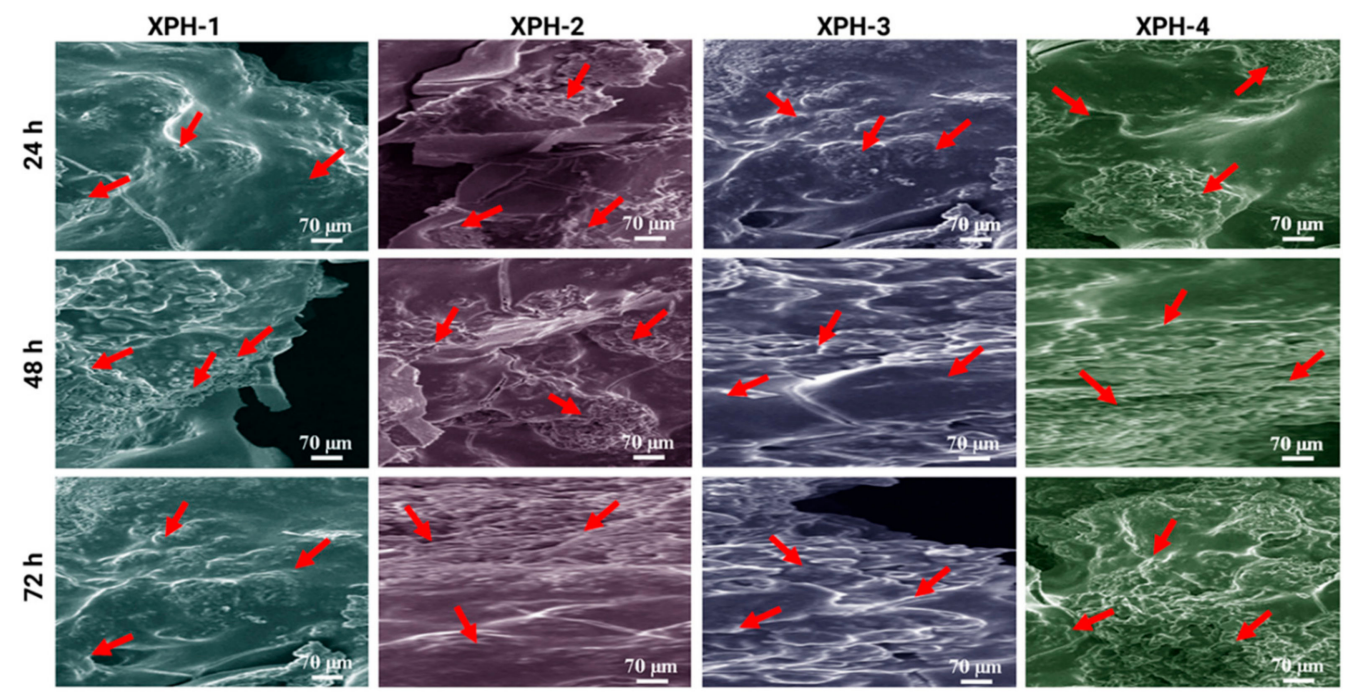

Figure 9. Presents the SEM analysis of cell culture and adherence for all hybrid nanocomposite scaffolds against MC3T3-E1 after 24, 48, and $72 \mathrm{~h}$ and red arrows indicate the culture and adherence of osteoblast cells.

\section{Conclusions}

The polymeric nanocomposites were synthesized through free radical polymerization to fabricate porous scaffolds via the freeze-drying technique. The physicochemical (morphology, porosity, wetting, swelling, biodegradation, and biomechanical, etc.) properties of the hybrid nanocomposite scaffolds were performed using different techniques. During analysis, it was observed that these properties can be optimized efferently by varying amounts of $\mathrm{TiO}_{2}$ NPs. The addition of optimized GO and different amounts of $\mathrm{TiO}_{2}$ NPs into the polymeric matrix enhanced the physicochemical and biomechanical characteristics of fabricated hybrid nanocomposite scaffolds that encouraged proliferation and cell attachment against MC3T3-E1 cell lines. XPH-4 exhibited the maximum mechanical behavior (strength $=13.31 \pm 2.45 \mathrm{MPa}$, Young's modulus $=300.85 \pm 1.90 \mathrm{MPa}$ ) with less pore size $(107.42 \pm 1.78 \mu \mathrm{m})$ and porosity $(44.32 \pm 2.14 \%)$ than other scaffold samples and XPH-1 had the least mechanical properties (strength $=2.96 \pm 2.14 \mathrm{MPa}$, Young's modulus $=39.56 \pm 2.14 \mathrm{MPa})$ with maximum pore size $(256.11 \pm 1.28 \mu \mathrm{m})$ and porosity $(79.97 \pm 1.32 \%)$ with $\sim 94.1 \%$ after $150 \mathrm{~min}$. Whereas, XPH-4 had the best biocompatibility, cell adherence, and proliferation with uniform interrelated porous structure and load-bearing behavior among all other scaffold samples. Hence, it is concluded from 
the consistent results of our studies that these hybrid nanocomposite scaffolds would be potential biomaterials in bone tissue engineering. Therefore, these hybrid nanocomposite scaffolds can be implanted to treat different bones with different mechanical and morphological properties to engineer the fracture bone tissue.

Author Contributions: Conceptualisation: M.U.A.K.; Data curation: M.U.A.K., A.H. (Adnan Haider), M.A.R. and S.I.A.R.; Formal analysis: M.U.A.K., H.M., S.I.A.R., A.H. (Anwarul Hassan) and A.H. (Adnan Haider); Funding acquisition: S.I.A.R. and H.M.; Investigation: M.U.A.K., M.A.R., A.H. (Anwarul Hassan) and S.I.A.R.; Methodology: M.U.A.K., A.H. (Adnan Haider), W.S.A.-A. and M.S.B.; Project administration: M.U.A.K., M.A.R., S.I.A.R. and R.A.; Resources: M.U.A.K., W.S.A.A., M.S.B. and S.I.A.R.; Software: M.U.A.K., H.M., A.H. (Anwarul Hassan) and R.A.; Supervision: M.U.A.K., M.A.R., S.I.A.R. and A.H. (Anwarul Hassan); Validation: M.U.A.K., H.M., R.A., S.I.A.R., A.H. (Anwarul Hassan) and M.A.R.; Visualisation: M.U.A.K., W.S.A.-A. and M.S.B.; Writing-original draft: M.U.A.K.; Writing—review \& editing, M.U.A.K., M.A.R., A.H. (Anwarul Hassan) and S.I.A.R. All authors have read and agreed to the published version of the manuscript.

Funding: The authors would like to thank Universiti Teknologi Malaysia for supporting this study under UTM-IIIG grant number 02M44.

Acknowledgments: This work has received article processing charges from Prince Sultan University and also thanks for the support of structures and materials lab at Prince Sultan University, Riyadh, Saudi Arabia.

Conflicts of Interest: The authors declare no conflict of interest.

\section{References}

1. Fanti, A.; Lodi, M.B.; Mazzarella, G. Enhancement of Cell Migration Rate Toward a Superparamagnetic Scaffold Using LF Magnetic Fields. IEEE Trans. Magn. 2016, 52, 1-8. [CrossRef]

2. Ottaviano, G.; Chiesa, R.; Feuchtinger, T.; Vickers, M.A.; Dickinson, A.; Gennery, A.R.; Veys, P.; Todryk, S. Adoptive T Cell Therapy Strategies for Viral Infections in Patients Receiving Haematopoietic Stem Cell Transplantation. Cells 2019, 8, 47. [CrossRef] [PubMed]

3. Khan, M.U.A.; Mehboob, H.; Razak, S.I.A.; Yahya, M.Y.; Yusof, A.H.M.; Ramlee, M.H.; Anand, T.J.S.; Hassan, R.; Aziz, A.; Amin, R. Development of Polymeric Nanocomposite (Xyloglucan-co-Methacrylic Acid/Hydroxyapatite/SiO2) Scaffold for Bone Tissue Engineering Applications-In-Vitro Antibacterial, Cytotoxicity and Cell Culture Evaluation. Polymers 2020, 12, 1238. [CrossRef]

4. Xu, H.-Y.; Gu, N. Magnetic responsive scaffolds and magnetic fields in bone repair and regeneration. Front. Mater. Sci. 2014, 8, 20-31. [CrossRef]

5. Khan, M.U.A.; Haider, S.; Haider, A.; Razak, S.I.A.; Kadir, M.R.A.; Shah, A.S.; Javed, A.; Shakir, I.; Al-Zahrani, A.A. Development of porous, antibacterial and biocompatible GO/n-HAp/bacterial cellulose/ $\beta$-glucan biocomposite scaffold for bone tissue engineering. Arab. J. Chem. 2021, 14, 102924. [CrossRef]

6. Zamri, M.F.M.A.; Bahru, R.; Amin, R.; Khan, M.U.A.; Razak, S.I.A.; Abu Hassan, S.; Kadir, M.R.A.; Nayan, N.H.M. Waste to health: A review of waste derived materials for tissue engineering. J. Clean. Prod. 2021, 290, 125792. [CrossRef]

7. Khan, M.U.A.; Razak, S.I.A.; Mehboob, H.; Kadir, M.R.A.; Anand, T.J.S.; Inam, F.; Shah, S.A.; Abdel-Haliem, M.E.F.; Amin, R. Synthesis and Characterization of Silver-Coated Polymeric Scaffolds for Bone Tissue Engineering: Antibacterial and In Vitro Evaluation of Cytotoxicity and Biocompatibility. ACS Omega 2021, 6, 4335-4346. [CrossRef]

8. Carayon, I.; Gaubert, A.; Mousli, Y.; Philippe, B. Electro-responsive hydrogels: Macromolecular and supramolecular approaches in the biomedical field. Biomater. Sci. 2020, 8, 5589-5600. [CrossRef]

9. Khan, M.U.A.; Raza, M.A.; Mehboob, H.; Kadir, M.R.A.; Razak, S.I.A.; Shah, S.A.; Iqbal, M.Z.; Amin, R. Development and in vitro evaluation of $\mathrm{K}$-carrageenan based polymeric hybrid nanocomposite scaffolds for bone tissue engineering. RSC Adv. 2020, 10, 40529-40542. [CrossRef]

10. Khan, M.U.A.; Haider, S.; Shah, S.A.; Abd Razak, S.I.; Hassan, S.A.; Kadir, M.R.A.; Haider, A. Arabinoxylan-co-AA/HAp/TiO 2 nanocomposite scaffold a potential material for bone tissue engineering: An in vitro study. Int. J. Biol. Macromol. 2020, 151, 584-594. [CrossRef]

11. Al-Arjan, W.S.; Khan, M.U.A.; Nazir, S.; Razak, S.I.A.; Kadir, M.R.A. Development of Arabinoxylan-Reinforced Apple Pectin/Graphene Oxide/Nano-Hydroxyapatite Based Nanocomposite Scaffolds with Controlled Release of Drug for Bone Tissue Engineering: In-Vitro Evaluation of Biocompatibility and Cytotoxicity against MC3T3-E1. Coatings 2020, 10, 1120. [CrossRef]

12. Khan, M.U.A.; Raza, M.A.; Razak, S.I.A.; Kadir, M.R.A.; Haider, A.; Shah, S.A.; Yusof, A.H.M.; Haider, S.; Shakir, I.; Aftab, S. Novel functional antimicrobial and biocompatible arabinoxylan/guar gum hydrogel for skin wound dressing applications. $J$. Tissue Eng. Regen. Med. 2020, 14, 1488-1501. [CrossRef] [PubMed]

13. Gunatillake, P.A.; Adhikari, R. Biodegradable synthetic polymers for tissue engineering. Eur. Cell Mater. 2003, 5, 1-16. [CrossRef] 
14. Khan, M.U.A.; Al-Thebaiti, M.A.; Hashmi, M.U.; Aftab, S.; Razak, S.I.A.A.; Abu Abu Hassan, S.; Kadir, M.R.A.A.; Amin, R. Synthesis of Silver-Coated Bioactive Nanocomposite Scaffolds Based on Grafted Beta-Glucan/Hydroxyapatite via Freeze-Drying Method: Anti-Microbial and Biocompatibility Evaluation for Bone Tissue Engineering. Materials 2020, 13, 971. [CrossRef] [PubMed]

15. Rao, S.H.; Harini, B.; Shadamarshan, R.P.K.; Balagangadharan, K.; Selvamurugan, N. Natural and synthetic polymers/bioceramics/bioactive compounds-mediated cell signalling in bone tissue engineering. Int. J. Biol. Macromol. 2018, 110, 88-96. [CrossRef]

16. Khan, M.A.; Razak, S.A.; Al Arjan, W.; Nazir, S.; Anand, T.S.; Mehboob, H.; Amin, R. Recent Advances in Biopolymeric Composite Materials for Tissue Engineering and Regenerative Medicines: A Review. Molecules 2021, 26, 619. [CrossRef]

17. Li, M.; Liu, J.; Cui, X.; Sun, G.; Hu, J.; Xu, S.; Yang, F.; Zhang, L.; Wang, X.; Tang, P. Osteogenesis effects of magnetic nanoparticles modified-porous scaffolds for the reconstruction of bone defect after bone tumor resection. Regen. Biomater. 2019, 6, 373-381. [CrossRef] [PubMed]

18. Lu, F.; Wu, R.; Shen, M.; Xie, L.; Liu, M.; Li, Y.; Xu, S.; Wan, L.; Yang, X.; Gao, C.; et al. Rational design of bioceramic scaffolds with tuning pore geometry by stereolithography: Microstructure evaluation and mechanical evolution. J. Eur. Ceram. Soc. 2021, 41, 1672-1682. [CrossRef]

19. Rasoulianboroujeni, M.; Kiaie, N.; Tabatabaei, F.S.; Yadegari, A.; Fahimipour, F.; Khoshroo, K.; Tayebi, L. Dual Porosity Proteinbased Scaffolds with Enhanced Cell Infiltration and Proliferation. Sci. Rep. 2018, 8, 14889. [CrossRef]

20. Repetto, G.; Del Peso, A.; Zurita, J.L. Neutral red uptake assay for the estimation of cell viability/cytotoxicity. Nat. Protoc. 2008, 3, 1125-1131. [CrossRef]

21. Liao, D.; Badour, C.; Liao, B. Preparation of nanosized $\mathrm{TiO}_{2} / \mathrm{ZnO}$ composite catalyst and its photocatalytic activity for degradation of methyl orange. J. Photochem. Photobiol. A Chem. 2008, 194, 11-19. [CrossRef]

22. Abd-Khorsand, S.; Saber-Samandari, S.; Saber-Samandari, S. Development of nanocomposite scaffolds based on TiO 2 doped in grafted chitosan/hydroxyapatite by freeze drying method and evaluation of biocompatibility. Int. J. Biol. Macromol. 2017, 101, 51-58. [CrossRef]

23. Webster, T.J.; Massa-Schlueter, E.A.; Smith, J.L.; Slamovich, E.B. Osteoblast response to hydroxyapatite doped with divalent and trivalent cations. Biomaterials 2004, 25, 2111-2121. [CrossRef] [PubMed]

24. Bouropoulos, N.; Stampolakis, A.; Mouzakis, D.E. Dynamic Mechanical Properties of Calcium Alginate-Hydroxyapatite Nanocomposite Hydrogels. Sci. Adv. Mater. 2010, 2, 239-242. [CrossRef]

25. Brundavanam, R.K.; Poinern, G.E.J.; Fawcett, D. Modelling the crystal structure of a $30 \mathrm{~nm}$ sized particle based hydroxyapatite powder synthesised under the influence of ultrasound irradiation from X-ray powder diffraction data. Am. J. Mater. Sci. 2013, 3, 84-90.

26. Thamaphat, K.; Limsuwan, P.; Ngotawornchai, B. Phase characterization of $\mathrm{TiO}_{2}$ powder by XRD and TEM. Kasetsart J. (Nat. Sci.) 2008, 42, 357-361.

27. Johari, N.; Hosseini, H.R.M.; Samadikuchaksaraei, A. Novel fluoridated silk fibroin/ $\mathrm{TiO}_{2}$ nanocomposite scaffolds for bone tissue engineering. Mater. Sci. Eng. C 2018, 82, 265-276. [CrossRef] [PubMed]

28. Civantos, A.; Domínguez, C.; Pino, R.J.; Setti, G.; Pavón, J.J.; Martínez-Campos, E.; Garcia, F.J.G.; Rodríguez, J.A.; Allain, J.P.; Torres, Y. Designing bioactive porous titanium interfaces to balance mechanical properties and in vitro cells behavior towards increased osseointegration. Surf. Coat. Technol. 2019, 368, 162-174. [CrossRef]

29. Pham, Q.P.; Sharma, A.U.; Mikos, A.G. Electrospun Poly( $\varepsilon$-caprolactone) Microfiber and Multilayer Nanofiber/Microfiber Scaffolds: Characterization of Scaffolds and Measurement of Cellular Infiltration. Biomacromolecules 2006, 7, 2796-2805. [CrossRef]

30. Lai, C.W.; Sreekantan, S. Single step formation of $\mathrm{C}-\mathrm{TiO}_{2}$ nanotubes: Influence of applied voltage and their photocatalytic activity under solar illumination. Int. J. Photoenergy 2013, 2013. [CrossRef]

31. Janovák, L.; Deák, Á.; Tallósy, S.P.; Sebők, D.; Csapó, E.; Bohinc, K.; Abram, A.; Pálinkó, I.; Dékány, I. Hydroxyapatite-enhanced structural, photocatalytic and antibacterial properties of photoreactive $\mathrm{TiO}_{2} / \mathrm{HAp} /$ polyacrylate hybrid thin films. Surf. Coat. Technol. 2017, 326, 316-326. [CrossRef]

32. Nie, J.; Zhou, J.; Huang, X.; Wang, L.; Liu, G.; Cheng, J. Effect of $\mathrm{TiO}_{2}$ doping on densification and mechanical properties of hydroxyapatite by microwave sintering. Ceram. Int. 2019, 45, 13647-13655. [CrossRef]

33. Jin, C.-Z.; Yang, Y.; Yang, X.-A.; Wang, S.-B.; Zhang, W.-B. Visible photocatalysis of Cr (VI) at g/L level in $\mathrm{Si} / \mathrm{N}_{-} \mathrm{TiO}{ }_{2}$ nanocrystals synthesized by one-step co-hydrolysis method. Chem. Eng. J. 2020, 398, 125641. [CrossRef]

34. Mondal, S.; Hoang, G.; Manivasagan, P.; Moorthy, M.S.; Nguyen, T.P.; Phan, T.T.V.; Kim, H.H.; Kim, M.H.; Nam, S.Y.; Oh, J. Nano-hydroxyapatite bioactive glass composite scaffold with enhanced mechanical and biological performance for tissue engineering application. Ceram. Int. 2018, 44, 15735-15746. [CrossRef]

35. Alagoz, A.S.; Rodriguez-Cabello, J.C.; Hasirci, V. PHBV wet-spun scaffold coated with ELR-REDV improves vascularization for bone tissue engineering. Biomed. Mater. 2018, 13, 055010. [CrossRef] [PubMed]

36. Anaya-Esparza, L.M.; Villagrán-de la Mora, Z.; Ruvalcaba-Gómez, J.M.; Romero-Toledo, R.; Sandoval-Contreras, T.; AguileraAguirre, S.; Montalvo-González, E.; Pérez-Larios, A. Use of titanium dioxide $\left(\mathrm{TiO}_{2}\right)$ nanoparticles as reinforcement agent of polysaccharide-based materials. Processes 2020, 8, 1395. [CrossRef]

37. Wang, Y.-W.; Chen, G.-Q.; Wu, Q.; Chen, J. Evaluation of three-dimensional scaffolds made of blends of hydroxyapatite and poly(3-hydroxybutyrate-co-3-hydroxyhexanoate) for bone reconstruction. Biomatererials 2004, 26, 899-904. [CrossRef] 
38. Li, J.; Hu, Y.; Liu, W.; Weng, X.; Dong, X.; Zhang, X.; Zhou, W. High Flux and Hydrophilic Fibrous Ultrafiltration Membranes Based on Electrospun Titanium Dioxide Nanoparticles/Polyethylene Oxide/Poly(vinylidene fluoride) Composite Scaffolds. J. Nanosci. Nanotechnol. 2017, 17, 9042-9049. [CrossRef]

39. Kang, L.; Zhao, L.; Yao, S.; Duan, C. A new architecture of super-hydrophilic $\beta$-SiAlON/graphene oxide ceramic membrane for enhanced anti-fouling and separation of water/oil emulsion. Ceram. Int. 2019, 45, 16717-16721. [CrossRef]

40. Hameed, P.; Gopal, V.; Bjorklund, S.; Ganvir, A.; Sen, D.; Markocsan, N.; Manivasagam, G. Axial Suspension Plasma Spraying: An ultimate technique to tailor Ti6Al4V surface with HAp for orthopaedic applications. Colloids Surf. B Biointerfaces 2019, 173, 806-815. [CrossRef]

41. Yang, Z.; Hao, X.; Chen, S.; Ma, Z.; Wang, W.; Wang, C.; Yue, L.; Sun, H.; Shao, Q.; Murugadoss, V.; et al. Long-term antibacterial stable reduced graphene oxide nanocomposites loaded with cuprous oxide nanoparticles. J. Colloid Interface Sci. 2019, 533, 13-23. [CrossRef] [PubMed]

42. Tan, Y.; Song, Y.; Zheng, Q. Hydrogen bonding-driven rheological modulation of chemically reduced graphene oxide/poly(vinyl alcohol) suspensions and its application in electrospinning. Nanoscale 2012, 4, 6997-7005. [CrossRef] [PubMed]

43. Allen, R.J.; Waclaw, B. Bacterial growth: A statistical physicist's guide. Rep. Prog. Phys. 2019, 82, 016601. [CrossRef] [PubMed]

44. Mahdy, E.A.; Sahbal, K.M.; Mabrouk, M.; Beherei, H.H.; Abdel-Monem, Y.K. Enhancement of glass-ceramic performance by TiO 2 doping: In vitro cell viability, proliferation, and differentiation. Ceram. Int. 2021, 47, 6251-6261. [CrossRef]

45. Bet, M.R.; Goissis, G.; Vargas, S.; Selistre-De-Araujo, H.S. Cell adhesion and cytotoxicity studies over polyanionic collagen surfaces with variable negative charge and wettability. Biomaterials 2003, 24, 131-137. [CrossRef]

46. Aslam Khan, M.U.; Haider, A.; Abd Razak, S.I.; Abdul Kadir, M.R.; Haider, S.; Shah, S.A.; Hasan, A.; Khan, R.; Khan, S.u.d. Arabinoxylan/graphene-oxide/nHAp-NPs/PVA bio-nano composite scaffolds for fractured bone healing. J. Tissue Eng. Regen. Med. 2021, 15, 322-335. [CrossRef] [PubMed]

47. Teymouri, S.; Calejo, M.T.; Hiltunen, M.; Sorkio, A.; Juuti-Uusitalo, K.; Skottman, H.; Kellomäki, M. Collagen-immobilized polyimide membranes for retinal pigment epithelial cell adherence and proliferation. Cogent Chem. 2017, 3, 1292593. [CrossRef]

48. Li, Z.; Qiu, J.; Du, L.Q.; Jia, L.; Liu, H.; Ge, S. TiO 2 nanorod arrays modified Ti substrates promote the adhesion, proliferation and osteogenic differentiation of human periodontal ligament stem cells. Mater. Sci. Eng. C 2017, 76, 684-691. [CrossRef] [PubMed]

49. Ghane, N.; Khalili, S.; Khorasani, S.N.; Neisiany, R.E.; Das, O.; Ramakrishna, S. Regeneration of the peripheral nerve via multifunctional electrospun scaffolds. J. Biomed. Mater. Res. Part A 2021, 109, 437-452. [CrossRef] [PubMed] 